\title{
Music as a necessary means of moral education: a case study from reconstruction of Confucian culture in Joseon Korea
}

\author{
So Jeong Park ${ }^{1}$
}

Received: 25 June 2015 / Revised: 8 July 2015/Accepted: 9 July 2015 / Published online: 1 August 2015 (C) Academy for International Communication of Chinese Culture and Springer-Verlag Berlin Heidelberg 2015

\begin{abstract}
This paper explores Confucian musical discourse as a valuable resource for mapping out contemporary culture. Stimulated by the advent of emerging music in pre-Qin period, wide and various debates resulted in exceptional emphasis on music, unparalleled in the world history. Music has been regarded as an indispensable part of Confucian moral education, not only for cultivating human nature but also for bringing up orderly society. This view promoted the concept of music closely combined with state rituals. Historically, music in this light has been a symbol of continuity of Confucian political ideal in the dynasties of China and of other East Asian countries such as Korea, Japan, and Vietnam. While those state-led productions of music contributed to the solidarity of the communities, they often exposed discrepancies between musical theories and practices. The reconstruction of Confucian ritual music in Joseon Korea is a worthwhile case of Confucian musical discourse, because it shows continuing significance in the following points. Firstly, the sources of ancient music were thoroughly reviewed and the revival of Confucian musical ideal was accordingly experimented. Secondly, the problematic phenomenon of theory overriding musical reality came into question and brought about heated controversy over the qualification for Joseon court music between
\end{abstract}

\footnotetext{
This paper was presented to the World Consortium for Research in Confucian Cultures, "Confucian Values in a Changing World Cultural Order," University of Hawai'i, East-West Center, 8-11 Oct 2014. Joseon (朝鮮) was a Korean kingdom which lasted for about five centuries: July 1392 to October 1897. In this paper, the transcriptions of Korean terms are based on Revised Romanization of Korean (RRK), which has been officially used in South Korea since 2000. If necessary, Romanization on McCuneReischauer system (MCR), still widely used in Western scholarly community, will be provided. For example, Joseon is Chosŏn in MCR. In some cases, I leave the original transliterations in quotation untouched and provide RRK.
}

So Jeong Park

selfsopark@gmail.com; sjpark@ntu.edu.sg

1 Nanyang Technological University, Singapore, Singapore 
Sino-Korean music and indigenous music. Thirdly, Joseon Confucian thinkers reexamined the following questions which had been taken for granted: Why can music be regarded as a necessary means of moral education? And which music is such music? Through this successful retrieval, they could keep Confucian musical discourse alive.

Keywords Music $\cdot$ Moral education - Confucian culture $\cdot$ Joseon Korea $\cdot$ Ritual music

\section{Introduction}

This paper explicates why music is indispensable in Confucian moral education and illustrates a musical reconstruction project in Joseon Korea as a successful case of Confucian musical discourse. I will argue that Confucian musical ideal in early China was not adequately handed down to posterity even though state sacrificial music, allegedly Confucian product, has always been regarded as the most desirable music throughout the official histories of the different dynasties in China. Early Confucian musical discourse properly appreciated music as a significant human experience but inattentive reading and superficial reception of Confucian musical outlook in the later periods made it appear just as a conservative view of state-led musical rite which was far from musical reality. What Confucian musical discourse anticipated is not limited to adhering to state sacrificial musical form or ancient type of music but open to reflection on what music really is to us.

The reinterpretation and recomposition of Confucian ritual music in young Joseon Korea proves that Confucian value had finally crossed the cultural and political borders and could be rejuvenated as an interactive model with actual sound and music in different cultures. Being a marginalized culture by centralized East Asian world order, Joseon Korea could break through the long fossilized meaning of Confucian ritual music and propose a new framework of Confucian musical ideal. By doing so, Joseon Korea envisioned a moral society with a mature music culture which would allow the acknowledged style and the indigenous tune to be mutually prosperous and old and new music not to interfere with the development of each other by sharing their musical value.

\section{Music in Confucian moral education}

Stimulated by the advent of emerging music in pre-Qin period, wide and various debates resulted in exceptional emphasis on music, unparalleled in world history. As a matter of fact, musical discourse was not the monopoly of Confucian thinkers but rather a common concern of pre-Qin thinkers. Confucius, however, is justifiably regarded as the first thinker who extensively examined the retrospective and contemporary musical texts and promoted music as a fundamental subject of his education system. His students, Mencius, Xunzi, and the unknown authors of the 
Book of Music (Yueji, 樂記) ${ }^{1}$ have developed Confucius' suggestive ideas into more applicable claims. Although their opinions differed and sometimes came into conflict with each other, they all were inspired with music as a necessary means of moral education.

The role that music played in Confucian moral education can be divided into two directions: cultivating human nature and bringing up harmonious society. However, none of these roles count on a simplistic connection between musicality and morality. Confucian understanding of music is more comprehensive and complex than usually described. It is told that Confucius could sing all genres of poetry with string accompaniment ${ }^{2}$ and that he devoted himself to the arrangement of Yă 雅 and Sòng 頌 in his last years when he returned to the homeland after a long exile. ${ }^{3}$ The former explains that Confucius was not only familiar with a certain genre of poems and songs, and the latter explains that he endorsed Zhou 周 traditional music. His endorsement of Zhou ritual music, however, does not necessarily show his propensity to musical conservatism or his fondness to Zhou melody but rather his reasonable appreciation of the ritual character of music in Zhou culture. Just as he did recognize the need for reformation in some ritualized actions, ${ }^{4}$ he would have been open to musical innovation if it could meet the spirit of the times. Indeed, the music that had impressed him most deeply was not $w \breve{u}$ 武 music which represented Zhou sacrificial music, but sháo 韶 music ${ }^{5}$ which had been recomposed in various states such as Qi 齊 and Lu 魯. ${ }^{6}$

Confucius was not an adherent of Zhou ritual itself but rather a believer in sustainable ritual into far distant future. He expanded the scope of ritual by retrospection of cultural tradition before the Zhou dynasty. ${ }^{7}$ Ritual is not only the social norm and but also the window through which we view the world. Ritual as "mode of framing action" creates "subjunctive universe." behaviors could be meaningful only when the participants maintain a shared community by performing those ritual behaviors and at the same time ritual shapes our behaviors and develops our characters. Ritual behaviors could never be fixed but only be maintained under the ever-changing process.

\footnotetext{
${ }^{1}$ Regarding the authors and the formation period of the Book of Music, see Park (2015). For transcription of the Mandarin pronunciations of Chinese character, I follow Hanyu Pinyin system which has replaced the former Romanization, Wade-Giles system, since the late twentieth century. The marks of 4 tones are provided, if needed.

2 See Shiji 史記, Book 47 “Kongzi Shijia 孔子世家”: “三百五篇, 孔子皆弦歌之.”

3 See Analects 9.15: “子曰: 吾自衛反魯, 然後樂正, 雅頌, 各得其所.”

4 See Analects 9.3: “子曰: 麻冕, 禮也. 今也, 純儉, 吾從眾. 拜下, 禮也. 今拜乎上, 泰也, 雖遠眾, 吾從 下.”

5 See Analects 3.25: “子謂韶, 盡美矣, 又盡善也. 謂武, 盡美矣, 未盡善也.”

6 Whereas Jizha (季札, a prince of Wu 吳 dukedom) enjoyed Shao musical performance in Lu 魯(See Zuozhuan, "Duke Xiang: year 29." [544 BCE]), Confucius (551-479 BCE) had not appreciated Shao music so much until he was deeply moved by Shao played in Qi 齊. See Analects 7.14: “子在齊聞韶, 三 月不知肉味, 曰:不圖為樂之至於斯也.”

7 See Analects 2.23: “子張問: 十世可知也? 子曰: 殷因於夏禮, 所損益, 可知也; 周因於殷禮, 所損益, 可知也. 其或繼周者, 雖百世, 可知也.”

${ }^{8}$ As for the concept of ritual as mode of faming action, see Seligman et al. (2008, p. 6, 14).
} 
Confucius might have come to the idea of correlation between ritual and music from Zhou musical performance closely combined into sacrificial rites, although a compound term "ritual and music (liyue, 禮樂)" was most probably his own coinage. ${ }^{9}$ Observing the dynamics of ritual and music which works on human behavior and emotion, Confucius never meant ritual and music as merely external practice and artifact. ${ }^{10}$ To Confucius, music was not just musical score or musical structure but something involved in entire human experience. The separation of music from poetry was under way in Confucius' time $^{11}$ and thus he divided a perhaps formerly integrated subject into poetry (shi, 詩) and music (yue, 樂) in his curriculum. ${ }^{12}$ In such a situation, "music" requires a higher degree of discipline than "poetry," which can be understood through the words, and "ritual," which can be learned by behaviors. On the top of that, as mentioned earlier, through personal experience he learned how deeply music can move people. Therefore, he put music at the final stage of the continuous learning process. ${ }^{13}$

When Mencius said "benevolent words do not have as profound an effect on the people as benevolent music," 14 he precisely caught Confucius's intention. To Mencius, music is joy of morality (rényi, 仁義) in nature. Once sparked by music, moral emotions cannot be stopped and so make "without realizing it one's feet begin to step in time to them and one's hands dance according to their rhythms."15 Music contributes to morality by enriching listener's susceptibility, not by preaching on morality.

Although Confucian thinkers believed that music exerts a profound influence on our emotional experience, it does not necessarily mean that specific music arouses specific emotion or that the good kinds of emotions are fostered by limiting everyone's musical experience to sage kings' compositions. Firstly, although the author of "The Roots of Music" seemingly proposed a correspondence theory between musical sounds and emotions, ${ }^{16}$ he merely made a fair statement that we express our different feelings in different sounds. A piece of music produced by a composer in a particular emotional state may allow a listener to sense the specific emotion but it does not follow that the listener should feel the same emotion. The reverse case can be true: Shallow people may not enjoy the music at all in which

\footnotetext{
9 As for a disyllabic word liyue, see Park (2013, p. 282).

10 See Analects 17.11: “子曰:禮云禮云!玉帛云乎哉! 樂云樂云!鍾鼓云乎哉!”

11 See Yu (2003).

12 According to Sima Qian, the main curriculum of Confucius includes poetry, governing principles, ritual, and music. See Shiji, Book 47: “孔子以詩書禮樂敎.”

13 See Analects 8.8: “興於詩, 立於禮, 成於樂”.

14 See Mencius 7A14: “仁言不如仁聲之入人深也.” The translation is Lau (1970, p. 184).

15 See Mencius 4A27: “仁之實, 事親是也. 義之實, 從兄是也. 智之實, 知斯二者弗去是也. 禮之實, 節 文斯二者是也. 樂之實, 樂斯二者, 樂則生矣; 生則惡可已也; 惡可已, 則不知足之蹈之, 手之舞之.” The quotation is Ivanhoe et al. (2001, p. 135).

16 See Book of Music, Chap. 1 “The Root of Music (yueben, 樂本)” in Sun (1995, pp. 976-977): “其哀心感 者, 其聲噍以殺; 其樂心感者, 其聲嘽以緩; 其喜心感者, 其聲發以散; 其怒心感者, 其聲粗以厲; 其敬心 感者, 其聲直以廉; 其愛心感者, 其聲和以柔, 六者, 非性也, 感於物而后動.” For the translation, see Cook (1995, pp. 27-29).
} 
virtuous people find great delight, as Xunzi pointed out. ${ }^{17}$ Secondly, it is also not plausible to say that Confucian thinkers tried to suppress negative emotions while promoting positive emotions by sage kings' music. When Confucius summed up the collection of poetry to say "swerving not from the right path," 18 he never excluded the folk songs which loaded with resentment, grief, despair and love from "the right path." Songs are invaluable because they reflect the sentiments of the people as they are. It would be abnormal if only pleasant tunes are heard in an oppressive society.

Ritual music is a significant means for moral education since we live in ritual and learn to synchronize our emotions to others' through music. Therefore, Confucian thinkers believed that we could get a proper channel of communication by establishing ritual and music in a proper way. In other words, if an appropriate ritual music is furnished in a newly established state, then all members of the state will be able to share its historical and cultural value. Xunzi pushed this point further to say that "when music is used to guide and regulate the desires, there is enjoyment but no disorder; when it is used for the desires with no thought of guidance, there is delusion but no enjoyment." ${ }^{\prime 19}$ Xunzi gave priority to music as social context over as personal indicator of morality and by doing so overburdened the leader of a community with a responsibility of guiding all entire people. Xunzian turn is to some extent inevitable in order to defend Confucian ritual and music theory against Mozi's criticism, but brought about side effect to restrain ritual music of spontaneous expression of moral cultivation.

\section{Pitfall of ritual music model}

Looking back, ritual music in this light has been a symbol of continuity of Confucian political ideal in the dynasties of China and of other East Asian countries such as Korea, Japan, and Vietnam. While those state-led productions of music perhaps contributed to the solidarity of the communities, they often exposed discrepancies between musical theories and practices. In China, where numerous dynasties alternated between conquering and being conquered repeating division and integration, the literal meaning of ritual music was continually emphasized and eventually fortified, while in reality ritual music rarely played its anticipated role and different genres of music originated from foreign and indigenous sources were thriving outside the fortress. ${ }^{20}$

Ironically, although Confucian ritual and music discourse was placed in a dominant position as state ideology in the early Han dynasty, it was gradually deprived of its vitality. Instead of liberal criticism, canonization of Confucian texts and careless juxtaposition of bipolar terminology were prevalent in Confucian academy. In early Confucian discourse, not all kinds of court music can be

\footnotetext{
17 See Xunzi, Chap. 20 “Discourse on Music (yuelun, 樂論).”: “樂者, 樂也. 君子樂得其道, 小人樂得其 欲.” For the translation, see Knoblock (1994, vol. 3/84).

18 See Analects 2.2: “子曰: 詩三百, 一言以蔽之, 曰: 思無邪.”

19 See Knoblock (1994, vol. 3/84).

20 See Yang (1997) and Lam (2013).
} 
advisable; neither should all kinds of new music be rejected. However, conceptual confusion has often arisen in the later period between several pairs of opposites such as court (雅頌, yăsòng) and folk music (風, fèng), old (古樂, gǔyuè) and new music (新樂, xīnyuè), sage kings' (先王之樂, xiānwáng zhī yuè) and secular music (世俗 之樂, shìsú zhī yuè), yăyuè (雅樂, lit. elegant music) and zhèngshēng (鄭聲, lit. tunes of Zheng) and etc.

Dichotomy of old and new music is virtually unsustainable because what we now call old music was once new music, and today's new music will soon be the old music. There cannot be a clear-cut boundary between old and new music. That is why Mencius said "whether it is the music of today or the music of antiquity makes no difference." 21 Most commentators in the later Confucian camp, however, were embarrassed to interpret this passage because they firmly believed that Confucius had promoted sháo 韶 music and demoted zhèngshēng 鄭聲, and regarded sháo music as equivalent of old music or sage king's music whereas zhèngshèng as new music or secular music. Consequently, they were quite at a loss, asking in return, "how can it be possible to say that the ancient music is the same as today's music?" and concluded that Mencius was eager to persuade the King of Qi and stated this passage just as a temporary expedient. ${ }^{22}$

A greater problem is that this interpretation was purely ideological on the basis of insubstantial parallels. Neither sháo nor zhèngshēng remained in any substantial form when the commentary was written. Zheng state was destroyed in $375 \mathrm{BCE}$ and Shun 舜, known as the author of sháo music, was merely a prehistoric figure. Actual music which might possibly correspond to the name of sháo or zhèngshèng seemed to remain until the Qin dynasty $(221-206 \text { BCE })^{23}$ but soon faded away. Since then, sháo and zhèngshèng have been no more than empty signs which lost their referents. Sháo was associated with the names of preferred music such as court, old, sage king's, virtuous music, and yăyuè, whereas zhèngshēng with harmful music such as folk, new, secular, licentious music and etc.

Then, what kind of music was zhèngshēng? Why has it become a synonym for all that bad music? Surely, Confucius said "zhèngsheng is licentious" (鄭聲淫, zhèngshēng yín) but this was mentioned just in regard to liturgical music of the state along with other state governing systems such as calendar and state vehicles, answering to Yanhui's question: how to govern a country. ${ }^{24}$ In the Analects, "zhèngshēng" appears three times in two places and Confucius only condemned "zhèngshēng" in relation to "yăyuè." 25 How do we explain this? One of reasonable

\footnotetext{
${ }^{21}$ See Mencius 1B1: “今之樂, 由古之樂也.” The translation is Lau (1970, p. 60).

${ }^{22}$ See Zhuxi 朱喜, Mengzi Jizhu 孟子集註: “范氏日: 戰國之時, 民窮財盡, 人君獨以南面之樂,自奉其 身. 孟子切於救民,故因齊王之好樂,開導其善心, 深勸其與民同樂, 以為今樂猶古樂, 其實今樂古樂, 何可同也? 但與民同樂,則無古今之異耳. 若必欲以禮樂治天下, 當如孔子之言, 必用韶舞, 必放鄭聲. 蓋孔子之言,為邦之正道,孟子之言,救時之急務, 所以不同.”

${ }^{23}$ See Shiji, Book 27 “Lisi Liezhuan 李斯列傳: 夫擊鶽吒缶彈筝搏髀, 而歌呼鳴鳴快耳目者, 真秦之聲 也; 鄭、衛、桑閒、昭、虞、武、象者, 異國之樂也. 今弃擊寉吒缶而就鄭、衛,退彈箏而取昭、虞, 若是者何也? 快意當前,適觀而已矣.”

${ }^{24}$ See Analects 15.11: “顔淵問為邦. 子曰: 行夏之時, 乘殷之輅. 服周之冕. 曰: 樂則韶舞. 放鄭聲, 遠 侫人; 鄭聲淫,侫人殆.”

${ }^{25}$ See Analects 17.18: “惡紫之奪朱也. 惡鄭聲之亂雅樂也. 惡利口之覆邦家者.”
} 
accounts is that "zhèngshèng" is a kind of music which could be a threat to ritual music performed at court just as clever talkers (位人, ningrén or 利口, likǒu) were undermining both state and clan. ${ }^{26}$ If a clever talker didn't have any status at court, he could have no way of undermining the state. Likewise, if "zhèngshèng" were not performed at court but merely popular songs among the folks, it could have not threatened to court music. That is to say, Confucius was not rejecting all the tunes or words of Zheng music or all kinds of musical innovation but rather blaming "zhèngshèng" on disturbing the proper performance of ritual music. When one of his disciples, Zixia 子夏, attacked Zheng music, the target was nothing but court music being performed at the palace of Marquis Wen of Wei (魏文侯, r. 445-396 BCE). ${ }^{27}$ Although Zixia turned down Zheng music on the ground of its deficiency of refinement and morality deserving to review, it was surely a form of court music which had an assortment of poetry, melody, and dance with instrumental accompaniment.

As we have seen it, zhèngshēng was at first used as a pronoun for innovative musical performance which prevailed in powerful states and so was a threat to authentic performance of ritual music at the times of Confucius. Later, it was overloaded with all sorts of decadent trend in music by being designated as a representative music contending with traditional music. Confucius was not opposed to all kinds of innovative music neither vernacular musical practice and yet he contemplated an enduring value from Zhou ritual music, not being swept away by the waves of new music. From one of major Confucian viewpoints such as Zixia's, a new trend of music was not so much worthy as the ancient music, where one could get much more value than just entertainment if we appropriately tasted. Zhèngshēng, which had once been designated as a problematic kind of music, was solidified as a synonym of all that bad music in this major lineage.

Unfortunately, neither Zigong's adaptable position which was more liberal to new music prevailing at the time ${ }^{28}$ nor Mencius's bold opinion that new tunes could also infuse people with moral sensibility was ripened into an interactive model of ritual and music. The problem was that "ritual and music" turned into almost an empty slogan. Successive emperors in China would mostly maintain the existing court music in status quo which they believed to be "ritual and music" and occasionally reinforce their ritual music with reorganization of the orchestral ensembles. To be communicated to the people and thus to be an influential means of moral education, the statewide enterprise of ritual music should be effectively combined to continuously emerging new music from all various sources and reconstructed to meet the emotional and musical sensibility of the people at the time. Yet, the ideological move in later Confucian circles only deepened the gulf between new tunes and court music. As Chinese musicologists point out, the court ritual music has become rigid since Qin and Han dynasties. The rulers kept

\footnotetext{
${ }^{26}$ For the context of "clever talker", see Footnotes 22 and 23. For the translation, refer to Ivanhoe et al. (2001, p. 45).

27 See Book of Music, Chap. 8 "Marquis Wen of Wei (魏文侯).”

28 See Book of Music, Chap. 11 "Music Master Yi (師乙)." I discussed this in my conference paper entitled "What Music Ought to be: The first debate on music in early China," which was presented at the 18th ISCP Conference in July, 2013.
} 
collecting and reorganizing yăyuè but nobody really understood it and there was no influence on their people at all. ${ }^{29}$

In recent studies, it is observed that there were most extensive and dissonant "discrepancies between historical and modern hearing of the Southern Song musical culture." ${ }^{30}$ Interestingly enough, the state sacrificial music of the Southern Song China (南宋, 1127-1275) was actually based on what was called "Grand and Splendid Ceremonial Music (Dàchéng yăyuè 大晟雅樂 or Dàchéngyuè 大晟樂)” reconstructed by Huizong of Northern Song (北宋徽宗 r. 1100-1125) in 1105. Huizong, who was a well versed musician as well as a literary artist but not an honorable statesman, painstakingly studied all the literature on ritual music and reconstructed grand court music, which is rated as the best restoration of the court music done in the entire Chinese history. ${ }^{31}$ But this faithfully restored court music didn't ensure its author political success. In 1126, Huizong had to abdicate the throne in favor of his son pushed by Jurchen invasion ${ }^{32}$ and Northern Song died out in the next year. This shows the complete failure of ritual and music model in the later Confucian camp.

\section{Musical enterprise of joseon Korea}

The very "Grand and Splendid Ceremonial Music (kr. Daeseong Aak; Taesŏng Aak in MRK, hereafter "Daeseong Aak")," however, had a profound impact on a neighboring country, Goryeo (高麗, Koryŏ in MRK), the previous dynasty of Joseon Korea. Since the court music was introduced from Song China in the early twelfth century, Goryeo seemed to have developed it quite well for a considerable period. According to the record of a literary man, Xú jīng 徐兢, ${ }^{33}$ who had visited to Goryeo accompanying with the envoys in $1124,{ }^{34}$ "the dance and music in the court of Goryeo were very impressive and worth to see." $35 \mathrm{He}$ found that the first introduction of the court music into Goryeo was traced back to Shenzong of Northern Song (北宋神宗 r. 1067-1085) in his early reign (the era of xining 熙寧: 1068-1077) ${ }^{36}$ and Daeseong Aak was introduced to Goryeo by an official request in $1116 .{ }^{37}$ It is said that not only the set of musical instruments but musicians and

\footnotetext{
29 See Yang (1997, pp. 1-126).

30 See Lam (2013, p. 109).

31 See Yang (1997, pp. 2-191).

32 Jurchen Jin (金), which had been looked down upon as barbarians by Huaxia dynasties of China, demoted Huizong to call "Muddled Virtue" (Hūndégōng 昏德公). Dàchéng yăyuè turned out to be a kind of "the music of a lost state."

33 As for the text of Xú jīng's Xuānhé fèngshǐ gāolí tújīng 《宣和奉使高麗圖經》, refer to http://ctext. org/wiki.pl?if=gb\&chapter=417946 [中國哲學書電子化計劃].

34 It is equivalent to the 2nd year of Injong (仁宗: 王楷, r. 1122-1146) of Goryeo dynasty.

35 Ibid. Book 40: “樂舞益盛, 可以觀聽”.

36 The period is equivalent to the reign of Munjong (文宗: 王徽, r. 1046-1083) of Goryeo.

37 It is arguable whether the exact year is 1116 or 1117. If 1116, then corresponds to the 11th year of Yejong (睿宗: 王俣, r. 1105-1122) of Goryeo.
} 
musical scores also were introduced, and that not only a type of sacrificial music, yăyuè, but a kind of banquet music, yànyuè 燕樂, also arrived. ${ }^{38}$

When King Sejong of Joseon (世宗: 李裪 r. 1418-1450) embarked on the enterprise of reconstructing ritual music, Daeseong Aak (大晟雅樂), loosely remained in existence as court music inheriting from the Goryeo dynasty. Along with this, there were another genres handed down such as dangak (唐樂, Chinese music) and sogak (俗樂, folk music) and/or hyangak (鄉樂, indigenous music) in the court of Joseon. Differently from the case of the extremely stretched term "yăyue" in China, "aak (雅 樂)" in Korea, both Goryeo and Joseon, solely denoted "Daeseong Aak.",39 "Aak" was not all kinds of court music or ancient sage king's music but a specific genre name for the music imported from Song, developed in Goryeo, and handed down to the early Joseon. ${ }^{40}$ It is most likely because Daeseong Aak was introduced through a very special route as aforementioned. All other music imported from China before the introduction of Daeseong Aak was instead called dangak 唐樂 in a sense of "Chinese or foreign music" and was merged into sogak (俗樂, folk music) together with hyangak (鄉樂, indigenous music) in the reign of Sejo (世祖: 李瑈 r. 1455-1468).

In many aspects, the reconstruction of ritual music in the early Joseon which Sejong initiated and Sejo propelled was different from the restoration of ritual music which many rulers of China had attempted. Firstly, folk music and indigenous tunes were transformed into the style of advanced music and included in the scope of court music and thereby aak was relativized. They respected aak as the most advanced music in the world of those days and at the same time legitimated their own indigenous tunes and made efficient use of foreign music that had long been accommodated. Secondly, the misplaced juxtaposition between new music and undesirable music was soberly questioned. Although the kings of Joseon and their musicians considered the music of the ancient three dynasties ${ }^{41}$ as an ideal model, ${ }^{42}$ they didn't think they could realize their ideal only by restoring the ancient music intact. Instead of adhering to an elusive model of ancient sage kings' music, they made every possible effort to produce their own ritual music, comprehensive in theory and effective in practice. They were clearly aware that the newly composed

\footnotetext{
38 Regarding the spread of Northern Song ceremonial music into Goryeo dynasty, see Yang (1997, pp. 2213).

39 See Provine (1978, p. 49). “(1) aak, ritual music of Chinese origin, performed in a supposedly Chinese style; (2) tangak, entertainment music of Chinese origin, performed in a Koreanized style; and (3) hyangak, purely indigenous music."

${ }^{40}$ See Provine (1992, p. 91). "Aak, unlike Chinese yayue and Japanese gagaku (both written with the same Chinese characters), is not a collective term for a number of court music genres, though some Koreans have loosely used the word in that sense in the present century. Rather, the term aak identifies a specific genre of Korean ritual music which is now performed in context only in the Sacrifice to Confucius, though in earlier centuries it was also played in a further five state sacrificial rites."

41 They are the Xia, Shang, and Zhou dynasties. Refer to Analects 3.14 and 15.25.

42 Refer to Taejo 4/4/25 (1395): “恭惟主上殿下, 制禮作樂, 動法三代之盛, ” Sejong 14/3/12 (1432): “然禮樂，自三代以下，雖中朝未得其正,” and Jeongjo 15/1/11 (1791): “我朝立國規模, 在三代則姬 周是學, 在後世則趙宋是效, 禮樂文物燦然備具.” Dates are in order of the reign year, month, and day [yy/mm/dd]. Source: Guksa Pyeonchan Wiwonhoe (National Institute of Korean History), Joseon wangjo sillok (朝鮮王朝實錄, The Annals of the Joseon Dynasty. Hereafter JWS). http://sillok.history.go.kr/ main/main.jsp.
} 
court music on the basis of native tune should be called "new music (新樂, kr. sinak ch. xinyuè)" "43 rather than aak, old music or sage king's music. Thirdly, the revival of ritual music in Joseon Korea contributed to the awareness of cultural identity and the development of cultural diversity. The more matured their musical understanding, the more they felt keenly the difference between their own musical tastes and those of Chinese aak. This awareness motivated the creation of native court music and the new notation system in order to record the native. ${ }^{44}$ The newly composed sinak, the reconstructed aak and the accommodated dangak coexisted in the Joseon courtyard and each had a proper usage.

It is right to say that the Joseon Dynasty envisioned its national ideal on the foundation of Neo-Confucianism ${ }^{45}$ and accordingly Sejong, whose reign is often called Korean Renaissance, ${ }^{46}$ can be regarded as a Confucian king. However, he was not a mere adherent of Confucianism but a mature thinker who reflected on how to adapt Confucian value for the new born Korea which had a different language and musical structure. What he had achieved in music was never cast "in the Chinese mold," 47 unlike commonly misunderstood. The restoration of " $a a k$ " was quite successfully done to the extent of "embodying certain ancient characteristics" and "in the course of their work, the Korean scholar made copies of the original sources for a set of Chinese ritual melodies which have since been neglected in China herself." 48 Nevertheless, Sejong's enterprise was heading in a different direction from the preservation of traditional aak. As aforementioned, he ventured to Koreanize ritual music or, conversely, to ritualize the indigenous tunes and this project embroiled in a long lasting dispute. ${ }^{49}$

The idea of Koreanized ritual music might not have been conceived from the beginning but became gradually ripe in the course of researching Chinese musical scholarship and applying it to Joseon musical landscape. In 1420, the second year of his reign, Sejong regarded the words of indigenous music as vulgar and tried to change them ${ }^{50}$ but after a while he began to doubt why we should abruptly play a

\footnotetext{
43 There were successive debates on the legitimation of folk tunes as court music. The Joseon government officers who were faithful to ideological Confucianism stubbornly objected to accept "new music (sinak)" as court music. Therefore, "sinak" which Sejong had newly composed as court music was not used as until Sejo carried out the massive reorganization of ritual music focused on "new music." Refer to JWS, Sejong 31/12/11 (1449) and Sejo 6/4/22 (1460).

44 See Kwon (2010): "Jeongganbo is a type of notation that can display the pitches and lengths of the notes. King Sejong had Jeongganbo created in order to overcome the limitations of existing musical notations...the most significant reason for the invention of Jeongganbo was that one could not record Hyang-ak (native court music) with the existing notation systems since they had essentially been made for Dang-ak from China. As Korean music had more variations in the lengths of notes than Chinese music, notation that recorded only the pitches was inappropriate."

45 See Deuchler (1980).

46 See Condit (1984).

47 See Provine (1988, p. 143).

48 See Provine (1988, p. 141).

49 There were several long-lasting debates such as on new ritual music, female musicians, and usage of each genre. For the designation of new ritual music, refer to JWS, Sejong 31/12/10 (1449) and Seongjong 9/11/7 (1478).

50 See JWS, Sejong 2/1[leap month]/19 (1420): “上曰: 宴享時, 常用鄉樂, 甚爲鄙俚。其令市季良、 趙庸、鄭以吾等以獻壽之意、警戒之辭, 各製歌詞三首”
} 
foreign music at the ancestral sacrifices instead of native music which was the usual favorites in their lifetime. ${ }^{51}$ Joseon elites educated in Confucianism presented a memorial to Sejong that indigenous musical performance should be expelled not only from the ancestral sacrifices but also from all other sacrifices and he accepted it. ${ }^{52}$ To musicians such as Bak Yeon (朴堧: 1378-1458), who was well versed in early Chinese musical scholarship, the aim of Joseon ritual music project was nothing but the complete restoration of what Chinese classics said through the rigorous investigation. ${ }^{53}$ However, the discordance between Chinese and Korean music were repeatedly reported such as different scales, standard pitches (宮, gung), tonal structures, and performance style. ${ }^{54}$ Sejong was awakened to a new significance that the indigenous music and Chinese-originated music aak were surely different and therefore it would be impossible and unnecessary to use aak in all types of court activities. ${ }^{55}$ After long trials and tribulations, in the 29th year of his reign (1447), Sejong finally released new ritual music. Although he wanted to widely use the new ritual music and also to perform at the royal ancestors' shrine, ${ }^{56}$ his wishes were not carried out until his son Sejo, who was deeply versed in music, ${ }^{57}$ took a decisive step towards a new phase. ${ }^{58}$ The debates between Sinocentrism and the indigenous move continued even after but the basic conception and structure of Joseon musical enterprise ${ }^{59}$ has remained through the entire history of Joseon Korea (Tables 1, 2).

\footnotetext{
${ }^{51}$ See JWS, Sejong 7/10/15 (1425): “且我國本習㰾樂, 宗廟之祭, 先奏唐樂, 至於三獻之時, 乃奏鄉 樂。以祖考平日之所聞者用之何如? 其與孟思誠議焉。”

52 See JWS, Sejong 10/1/4 (1428): “禮曹啓: 曾令宗廟祭, 勿奏鄉樂, 請於圓壇、社稷、風雲雷雨、零 祀、先農、先螢、釋奠等祭, 亦勿用鄉樂。從之。”

${ }^{53}$ See JWS, Sejong 12/2/19 (1430).

${ }^{54}$ See JWS, Sejong 12/2/19 and 12/7/8.

${ }^{55}$ See JWS, Sejong 12/9/11 (1430): “上謂左右曰: 雅樂, 本非我國之聲, 實中國之音也。中國之人平 日聞之熟矣, 奏之祭祀宜矣, 我國之人, 則生而聞㰾樂, 歿而奏雅樂, 何如? 沉雅樂, 中國歷代所製不 同, 而黃鍾之聲, 且有高下。是知雅樂之制, 中國亦未定也, 故予欲於朝會及賀禮, 皆奏雅樂, 而恐未 得製作之中也。以黃鍾之管而候氣, 亦未易爲也。”

56 See JWS, Sejong 29/6/4 (1447): “今降《龍飛御天歌》, 乃爲歌詠祖宗盛德神功而作, 所宜上下通 用, 以極稱揚之意, 不可止爲宗廟之用。《與民樂》、《致和平》、《醉豐亨》等樂, 於公私燕享, 并許通用。朝參及拜表箋日出宮時則《與民樂縵》, 朝參日還宮時及拜表箋迎詔栜行路時則《與 民樂令》, 皆用黃鍾宮”.

57 Sejong set a high value on musical ability of Sejo (Jinpyeong 晋平 when he was a prince). See JWS, Sejo, Preface: “世宗又謂文宗曰:知樂者, 我國中獨晋平耳, 前後所未有者也。”

${ }^{58}$ See JWS, Sejo 6/4/22 (1460): “御書下樂學都監曰: 制禮作樂, 非聖人不能也。是故歷歲千萬而無 或有更張者, 聖人出世難故也。所謂禮壞樂崩者, 只由此耳。世宗以天縱聖智, 制諸樂舞, 未及用 之。到今雖不暇於崇文閱武, 而此時不擧, 則後將廢棄矣, 豈不惜哉? 且工人非取於軍士, 樂署亦所 常肄, 自今肄《定大業》、《保太平》、《發祥》、《鳳來儀》新樂而盡廢舊樂 。”; Sejo 10/1/14 (1464): “上親祀宗廟, 奏新制定大業、保太平之樂。”

59 Seong Hyeon (成俔, 1439-1540), who was a chair of Jangagwon (掌樂院, Ministry of Music in Joseon), summarized the gist of Joseon musical project as follows. See his anthology, Heobaekdang Munjib 《虛白堂文集》, “The Record of Jangagwon (掌樂院題名記)”: “人不可不知樂也, 不知樂則湮 鬱閉塞而無以宣其氣。國不可一日無樂也, 無樂則㸃湽鄙俚而無以致其和。是故先王立樂之方, 設 樂之官,因人心之所同,而有所感發徵創焉。於是謳謠歌詠以發之, 鍾鼓管箴以寓之,聲曲音律以正 之, 疾徐経調以節之。用之朝廷則上下懌, 用之郊廟則鬼神感, 用之閏門、用之鄉黨, 悉皆欨歌奮 揚、鼓舞文明,而轉移風俗矣。” Source: Institute for the Translation of Korean Classic, Hanguk Gojeon Jonghap DB http://db.itkc.or.kr/itkcdb/mainIndexIframe.jsp.
} 
Table 1 Juxtaposition of bipolar terminology in early Confucian musical discourse

\begin{tabular}{|c|c|c|c|}
\hline $\begin{array}{l}\text { Texts where musical } \\
\text { terms appear in pairs }\end{array}$ & Harmful music & $\begin{array}{l}\text { Preferred } \\
\text { music }\end{array}$ & Remarks \\
\hline $\begin{array}{l}\text { Zuozhuan: Zhaogong 1st } \\
\text { year (BC541) }\end{array}$ & 煩手淫聲 & $\begin{array}{l}\text { 先王之樂 } \\
\text { (xiānwáng } \\
\text { zhī yuè) }\end{array}$ & $\begin{array}{l}\text { Playing styles at that time was contrasted } \\
\text { with Sage king's music (xiānwáng zhī } \\
\text { yuè) }\end{array}$ \\
\hline Analects & $\begin{array}{l}\text { 鄭聲 } \\
\quad \text { (zhèngshēng) }\end{array}$ & 韶、武 & $\begin{array}{l}\text { Tunes of Zheng (zhèngshēng) was spotted } \\
\text { as a threat to ritual music at court }\end{array}$ \\
\hline XingZiMingChu & $\begin{array}{l}\text { 鄭衛之樂 } \\
\text { 益(淫)樂 }\end{array}$ & $\begin{array}{l}\text { 妻、武、 } \\
\text { 韶、夏 } \\
\text { 古樂 (gŭyuè) }\end{array}$ & $\begin{array}{l}\text { Bipolarity of Zheng Wei music and "old } \\
\text { music" (gǔyuè) }\end{array}$ \\
\hline $\begin{array}{l}\text { Book of Music, Chap. 8: } \\
\text { Marquis of Wen of } \\
\text { Wei and Zixia }\end{array}$ & $\begin{array}{l}\text { 新樂 (xīnyuè) } \\
=\text { 鄭衛之音 } \\
\text { 溺音 }\end{array}$ & $\begin{array}{l}\text { 古樂 } \\
\text { 德音 (déyīn) }\end{array}$ & $\begin{array}{l}\text { Identification of Zheng Wei tunes and "new } \\
\text { music" (xīnyuè); redefining "old music" } \\
\text { as "virtuous tunes" (déȳin) }\end{array}$ \\
\hline $\begin{array}{l}\text { Mencius 1B1: } \\
\text { King of Xuan of Qi and } \\
\text { Mencius }\end{array}$ & 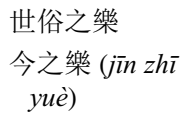 & $\begin{array}{l}\text { 先王之樂 } \\
\text { 古之樂 }\end{array}$ & $\begin{array}{l}\text { Identification of secular with } \\
\text { "contemporary"(jīn zhī yuè) and Sage } \\
\text { king's with "old Music" }\end{array}$ \\
\hline Xunzi, Chap. 17 & 鄭衛之音 & 雅頌之聲 & $\begin{array}{l}\text { Dichotomy of old and new music is not } \\
\text { adopted }\end{array}$ \\
\hline
\end{tabular}

Table 2 Different genres of the court music in the early Joseon Korea

\begin{tabular}{|c|c|c|c|}
\hline \multirow[t]{2}{*}{$\begin{array}{l}\text { Late } \\
\text { Goryeo }\end{array}$} & $\begin{array}{l}\text { Sogak (俗樂, folk music) } \\
\text { or Hyangak (鄉樂, } \\
\text { native music) }\end{array}$ & Dangak (唐樂) & $\begin{array}{l}\text { Aak }(\text { 雅樂 })=\text { Daeseong } \\
\text { Aak (大晟雅樂) in } 1116\end{array}$ \\
\hline & $\begin{array}{l}\text { Purely indigenous music } \\
\text { performed in Korean } \\
\text { style }\end{array}$ & $\begin{array}{l}\text { Entertainment music which had } \\
\text { Chinese origin but was } \\
\text { performed in a Koreanized style }\end{array}$ & $\begin{array}{l}\text { Ritual music of Chinese } \\
\text { origin performed in a } \\
\text { supposedly Chinese style }\end{array}$ \\
\hline \multirow[t]{3}{*}{$\begin{array}{l}\text { Early } \\
\text { Joseon }\end{array}$} & \multicolumn{2}{|c|}{$\begin{array}{l}\text { Sogak (俗樂, folk music) at Right office (Ubang, 右坊) of } \\
\text { Jangagwon (掌樂院) in } 1466^{\mathrm{b}}\end{array}$} & $\begin{array}{l}\text { Aak (雅樂) at left office } \\
\text { (Jwabang, 左坊) }\end{array}$ \\
\hline & $\begin{array}{l}\text { New ritual music based } \\
\text { on indigenous tune }\end{array}$ & $\begin{array}{l}\text { Maintained as entertainment and } \\
\text { marching music }\end{array}$ & Confucian sacrificial music \\
\hline & $\begin{array}{l}\text { Jeongdaeeop (定大業), } \\
\text { Botaepyeong (保太平), } \\
\text { Yeomillak (與民樂) }\end{array}$ & & \\
\hline $\begin{array}{c}\text { Present } \\
\text { days }\end{array}$ & $\begin{array}{l}\text { Jongmyo jeryeak (宗廟祭 } \\
\text { 禮樂) }\end{array}$ & & $\begin{array}{l}\text { Munmyo jeryeak (文廟祭禮 } \\
\text { 樂) }\end{array}$ \\
\hline
\end{tabular}

a Sogak and hyangak were interchangeable terms in the Goryeo dynasty. See Goryeosa (高麗史), Book 71, Record 25, “Akji (樂志, Record of Music)”. Source Guksa Pyeonchan Wiwonhoe (National Institute of Korean History). http://db.history.go.kr/KOREA/

b See Provine (1978, pp. 54-55) 


\section{Concluding remarks}

Confucian musical discourse is useful even today as a valuable resource for mapping out contemporary culture. A successful case of Korean reconstruction shows continual significance in the following points. Firstly, the sources of ancient music were thoroughly reviewed and the revival of Confucian musical ideal was accordingly experimented. Secondly, the problematic phenomenon of theory overriding musical reality came into question and brought about heated controversy over the qualification for Joseon court music between Sino-Korean music and indigenous music. Thirdly, Joseon Confucian thinkers reexamined the following questions which had been taken for granted: Why can music be regarded as a necessary means of moral education? And which music is such music? These are perennial questions which should be continuously asked if one would keep Confucian musical discourse alive.

The retrieval of Confucian ritual music in Joseon Korea is a worthwhile case of Confucian musical discourse. On one hand, it shared the same orientation as early Confucian ideal in that it tried to promote moral edification and social cohesion through the reconstruction of court music. The concept of music closely combined with state rituals bloomed into reality and produced substantial content. On the other hand, it broke through the fossilized Confucian value system of those days such as dichotomy of old and new music. In this light, Koreanization of ritual music was an indispensible step for the rejuvenation of Confucian culture. Joseon Korea could achieve a musical and cultural independence only by realizing its marginalized position and actively responding to it. The awareness of its own musical culture based on the recognition of musical susceptibility motivated Sejong to make new ritual music for everyone in Joseon, which even uneducated people could enjoy and expressed the harmony between ruler and subject. ${ }^{60}$ It reminds us of Mencius's claim that new music and old music make no difference as long as the enjoyment of the music can be shared with the people. It may not a coincidence that the list of new ritual music (sinak 新樂) included Yeomillak (與民樂), the term closely associated with Mencius's ideal.

\section{References}

Condit, J. (1984). Music of the Korean renaissance songs and dances of the fifteenth century. Cambridge: Cambridge University Press.

Cook, S. (1995). Yue Ji 樂記: Record of music: Introduction, translation, notes, and commentary. Asian Music, 26(2), 1-96.

Deuchler, M. (1980). Neo-Confucianism: The impulse for social action in early Yi Korea. Journal of Korean Studies. vol. 2, pp. 71-111. Center for Korea Studies, University of Washington.

Ivanhoe, P. J., \& Van Norden, B. W. (Eds.). (2001). Readings in classical Chinese philosophy. Indianapolis: Hackett.

\footnotetext{
${ }^{60}$ See JWS, Sejong 15/11/27 (1433) “雖愚夫愚婦, 亦當謌詠、舞詠者也。…聲氣之和，雖未及於 虞、周, 贊美之義, 實無愧於雅頌, 上項詩謌樂章, 群臣营然莫知, 豈君臣相悅之樂乎? 伏望殿下, 察 臣愚衷, 憐臣至情, 特命做司, 俾令大小臣僚, 會禮樂章, 靡所不知, 誦其詩、味其義, 當其侍宴之日, 克盡和樂恭敬之義, 則庶有補於風化之萬一矣。”
} 
Knoblock, J. (1988/1990/1994). Xunzi: A translation and study of the complete works (Vol. 1/2/3). California: Stanford University Press.

Kwon, O. S. (2010). History of Korean notation. In Musical notations of Korea (pp. 2-19).

Lam, J. S. C. (2013). Music, sound, and site: A case study from Southern Song China (1127-1275). In P.-K. Cheng \& K. W. Fan (Eds.), New perspectives on the research of Chinese culture. Singapore: Springer.

Lau, D. C. (1970). Mencius (trans.). Harmondsworth: Penguin.

Park, S. J. (2013). Sound, tone, and music in early China: The philosophical foundation of Chinese sound culture. In Inter-culutrality and philosophic discourse. Cambridge Scholar Publishing.

Park, S. J. (2015). On diverse nature of the book of music in terms of pre-Qin thought (先秦思想中《乐 记》的不同面向-以诸子的礼乐批判以及音乐术语的发展为核心). Journal of Literature, History \& Philosophy 文史哲. Shandong 山东: 《文史哲》编辑部.

Provine, R. C. (1978). Who's in charge here?: The Musical bureaucracy in the early Yi dynasty court (1392-1466). Asian Music (Korean Music Issue), 9(2), 48-58.

Provine, R. C. (1988). Essays on Sino-Korean musicology: Early sources for Korean ritual music. Seoul: IL JI SA.

Provine, R. C. (1992). The Korean courtyard ensemble for ritual music (Aak). Yearbook for Traditional Music, 24, 91-117.

Seligman, A. B., Weller, R. P., Puett, M. J., \& Simon, B. (2008). Ritual and its consequences: An essay on the limit of sincerity. Oxford University Press.

Sun, X. D. 孫希旦 (1995). A collective explanation of the book of ritual 禮記集解, Beijing: Zhonghua Shuju 中華書局.

Yang, Y. L. 楊蔭瀏 (1997). A draft history of ancient Chinese music 中國古代音樂史稿, Taipei 臺北: Dahong 大鴻.

Yu, Z. H. 俞志慧 (2003). Confucius on poetry: Interpretative features and its role in the history of poetics (竹書〈孔子詩論〉的論詩特點及其詩學史地位). Hanxue Yanjiu 漢學研究. 21(1), 23-45. 